\title{
Editorial for Special Issue "Chemical, Mineralogical and Isotopic Studies of Diagenesis of Carbonate and Clastic Sediments"
}

\author{
Ihsan S. Al-Aasm ${ }^{1, * \mathbb{D}}$ and Howri Mansurbeg ${ }^{1,2}$ \\ 1 School of the Environment, University of Windsor, Windsor, ON N9B 3P4, Canada; \\ Howri.Mansurbeg@uwindsor.ca \\ 2 General Directorate of Scientific Research Center, Salahaddin University-Erbil, Erbil 44002, \\ The Kurdistan Region of Iraq, Iraq \\ * Correspondence: alaasm@uwindsor.ca
}

Received: 10 November 2020; Accepted: 18 November 2020; Published: 20 November 2020

Diagenesis of carbonates and clastic sediments encompasses the biochemical, mechanical and chemical changes that occur in sediments after deposition and prior to low-grade metamorphism. Parameters which, to a large extent, control diagenesis in carbonate and clastic sediments include primary composition of the sediments, depositional facies, pore water chemistry, burial-thermal and tectonic evolution of the basin, and paleo-climatic conditions [1-6].

Diagenetic processes involve a widespread chemical, mineralogical and isotopic modifications affected by original mineralogy of carbonate and clastic sediments. These diagenetic alterations will impose a major control on porosity and permeability and hence on hydrocarbon reservoirs, water aquifers as well as the presence of other important economic minerals [7-10].

This Special Issue "Chemical, Mineralogical and Isotopic Studies of Diagenesis of Carbonate and Clastic Sediments", is a collection of eight selected papers that show up to date detailed geochemical, geological and sedimentological data on the diagenesis.

The paper by Cantarero et al. [11], entitled "Fracturing and near-surface diagenesis of a silicified Miocene deltaic sequence: the Montjuic Hill (Barcelona)" provided petrographic and geochemical evidence for the diagenetic overprints within the deltaic sequence investigated. These diagenetic modifications were affected by fracturing and cementation of a variety of minerals, such as barite and silicates. The authors also discussed the sources and nature of the diagenetic fluids that affected these rocks.

Studies by Yang et al. [12], entitled "Effect of dolomitization on porosity during various sedimentation-diagenesis processes in carbonate reservoirs", present how complex diagenetic processes, such as dolomitization, can affect porosity development in carbonate reservoirs. Multiphase fluid flow and solute transport simulation was employed to investigate dolomitization and its effect on porosity evolution from deep carbonates in Tarim Basin, northwest China. The numerical modeling applied in this study quantified dolomitization and other diagenetic processes and their relationships to fluid composition and hydrodynamic characteristics in the basin.

Tortola et al. [13], in their paper entitled "Diagenetic pore fluid evolution and dolomitization of the Silurian and Devonian carbonates, Huron Domain of southwestern Ontario: petrographic, geochemical and fluid inclusion evidence", investigated the nature of diagenetic fluids in part of Michigan Basin using sedimentologic and geochemical tracers. In both age groups, the authors identified three types of dolomite replacement matrix: RD1 (precipitated at shallow burial conditions), RD2 and RD3 (formed at intermediate burial conditions). In addition, a coarse crystalline ferroan saddle dolomite cement (formed at intermediate burial conditions) filling fractures and vugs has been 
documented in the Silurian successions. Early- and late-stage calcite cement have been distinguished in both groups of formations including isopachous, syntaxial overgrowth, dogtooth, drusy and blocky calcite. The authors linked the different types of cements to the fluid-rock interactions, which are associated to the tectonic evolution of the basin.

A unique presence of diagenetic bipyramidal quartz and aragonite was discussed thoroughly by Herrero et al. [14], in their paper entitled "Diagenetic origin of bipyramidal quartz and hydrothermal aragonites within the Upper Triassic Saline succession of the Iberian Basin: implications for interpreting the burial-thermal evolution of the basin". The authors applied several analytical techniques to investigate the nature of these minerals, such as petrography, SEM, Raman and fluid inclusions. They were able to relate the formation of these minerals to tectonic and thermal evolution of the Iberian Basin. Fluid composition and timing of migration were suggested based on mineralogical and geochemical evidence.

Sun et al. [15], in their paper entitled "Clay minerals and element geochemistry of clastic reservoirs in the Xiaganchaigou Formation of the Lenghuqi area, northern Qaidam Basin, China", discussed the formation of clay minerals and their diagenetic modification in Oligocene sandstones deposited in the Qaidam Basin in China. They used mineralogical and geochemical techniques to characterize the clay minerals and assigned depositional, paleoclimatic and diagenetic environments to their formation.

In a paper by Ozyurat et al. [16], entitled "REE characteristics of Lower Cretaceous limestone succession in Gumushane, NE Turkey: implications for ocean paleoredox conditions and diagenetic alteration", the effect of paleoredox conditions on diagenetic alteration of carbonates was investigated using REE and other geochemical proxies. Water-rock interactions between seawater and the surrounding basaltic rocks have an important role on the distribution and behavior of REE in the studied limestones. This paper provided an excellent example on the validity of using REE and other geochemical tracers to investigate paleoocean redox conditions.

Diagenetic alteration of the Paleogene sandstone of the Lulehe Formation in northern Qaidam Basin in China was the subject of detailed mineralogical and geochemical investigation by Chen et al. [17], in their paper entitled "Origin and sources of minerals and their impact on the hydrocarbon reservoir quality of the Paleogene Lulehe Formation in the Eboliang area, northern Qaidam Basin, China". The effects of diagenetic processes, such as cementation, dissolution and compaction on reservoir quality were discussed in this paper. These processes resulted in heterogeneity of the reservoir.

Hydrothermal fluid flow and resultant diagenetic alteration of Mesozoic successions from Maritime Alps, SE France was the focus of a paper by Salih et al. [18], entitled "Geochemical and dynamic model of repeated hydrothermal injections in two Mesozoic successions, Provencal Domain, Maritime Alps, SE-France". The authors used field, petrographic and geochemical evidence to evaluate dolomitization in the studied stratigraphic sections. They attributed the formation of these dolomites to episodic fracturing related to the flow of multiple fluxes of hydrothermal fluids.

The papers in this Special Issue demonstrate the interplay between mineralogical and chemical changes in carbonates and clastic sediments and diagenetic processes, fluid flow, tectonics, mineral reactions at variable scales and environments from a variety of sedimentary basins. Quantitative analyses of diagenetic reactions in these sediments, using a multitude of techniques, are essential for understanding pathways of in different diagenetic environments. These papers offer exciting new analytical and modeling techniques for understanding diagenesis of sedimentary rocks in a variety of sedimentary basins under different tectonic and hydrodynamic regimes.

Author Contributions: I.S.A.-A. wrote this editorial; proof-read by H.M. All authors have read and agreed to the published version of the manuscript.

Acknowledgments: We thank the authors of the articles included in this Special Issue and the organizations that have financially supported the research in the areas related to this topic. We thank the Editorial Board for their suggestions which improved the quality of this editorial.

Conflicts of Interest: The author declares no conflict of interest. 


\section{References}

1. Moore, C.H. Carbonate Reservoirs; Elsevier: Amsterdam, The Netherlands, 2001; 444p.

2. Tucker, M.E.; Wright, P.V. Carbonate Sedimentology; Blackwell Sci. Publ.: Hoboken, NJ, USA, 1990; 482p.

3. Morad, S.; Al Suwaidi, M.; Mansurbeg, H.; Morad, D.; Cerini, A.; Paganoni, M.; Al-Aasm, I. Diagenesis of a limestone reservoit (Lower Cretaceous), Abu Dhabi, UAE: Comparison between the anticline crest and flanks. Sedimentol. Geol. 2019, 380, 127-142. [CrossRef]

4. Seibel, M.J.; James, N.P. Diagenesis of Miocene, incised valley-filling limestones; Provence, Southern France. Sedimentol. Geol. 2017, 347, 21-35. [CrossRef]

5. Goldstein, R.H.; Franseen, E.K. Meteoric calcite cementation: Diagenetic response to relative fall in sea-level and effect on porosity and permeability, Las Negras area, southeastern Spain. Sedimentol. Geol. 2017, $348,1-18$.

6. Burley, S.D.; Wordon, R. Sandstone Diagenesis: Recent and Ancient; Blackwell: Hoboken, NJ, USA, 2009.

7. James, N.P.; Jones, B. Origin of Carbonate Rocks; John Wiley \& Sons: Hoboken, NJ, USA, 2015.

8. Swart, P.K. The geochemistry of carbonate diagenesis: The past, present and future. Sedimentology 2015, 62, 1233-1304. [CrossRef]

9. Al-Aasm, I. Origin and characterization of hydrothermal dolomite in the Western Canada Sedimentary Basin. J. Geochem. Exp. 2003, 78-79, 9-15. [CrossRef]

10. Morad, D.; Nader, F.H.; Gasparrini, M.; Morad, S.; Rossi, C.; Marchionda, E.; Al Darmaki, F.; Martines, M.; Hellevang, H. Comparison of the diagenetic and reservoir quality evolution between the anticline crest and flank of an Upper Jurassic carbonate gas reservoir, Abu Dhabi, UAE. Sediment. Geol. 2018, 367, 96-113. [CrossRef]

11. Cantarero, I.; Parcerisa, D.; Plata, M.A.; Gomez-Gras, D.; Gomez-Rivas, E.; Martin-Martin, J.D.; Trave, A. Fracturing and near-surface diagenesis of a silicified Miocene deltaic sequence: The Montjuic Hill (Barcelona). Minerals 2020, 10, 135. [CrossRef]

12. Yang, L.; Yu, L.; Chen, D.; Liu, K.; Yang, P.; Li, X. Effect of dolomitization on porosity during Various sedimentation-diagenesis processes in carbonate reservoirs. Minerals 2020, 10, 574. [CrossRef]

13. Tortola, M.; Al-Aasm, I.S.; Crowe, R. Diagenetic and pore fluid evolution and dolomitization of the Silurian and Devonian carbonates, Huron Domain of southwestern Ontario: Petrographic, geochemical and fluid inclusion evidence. Minerals 2020, 10, 140. [CrossRef]

14. Herrero, M.; Marfil, R.; Escavy, J.I.; Al-Aasm, I.; Scherer, M. Diagenetic origin of bipyramidal quartz and hydrothermal aragonites within the Upper Triassic Saline succession of the Iberian Basin: Implications for interpreting the burial-thermal evolution of the basin. Minerals 2020, 10, 177. [CrossRef]

15. Sun, G.; Wang, Y.; Guo, J.; Wang, M.; Jiang, Y.; Pam, S. Clay minerals and element geochemistry of clastic reservoirs in the Xiaganchaigou Formation of the Lenghuqi area, northern Qaidam Basin, China. Minerals 2020, 9, 678. [CrossRef]

16. Ozyurt, M.; Kirmaci., M.Z.; Al-Aasm, I.; Hollis, C.; Tasli, K.; Kandemir, R. REE characteristics of Lower Cretaceous limestone succession in the Gumushane, NE Turkey: Implications of ocean paleoredox conditions and diagenetic alteration. Minerals 2020, 10, 683. [CrossRef]

17. Chen, B.; Wang, F.; Shi, J.; Chen, F.; Shi, H. Origin and sources of minerals and their impact on the hydrocarbon reservoir quality of the Paleogenelulehe Formation in the Eboliang area, northern Qaidam Basin, China. Minerals 2019, 9, 436. [CrossRef]

18. Salih, N.; Mansurbeg, H.; Preat, A. Geochemical and dynamic model of repeated hydrothermal injections in two Mesozoic successions, Provencal Domain, Maritime Alps, SE-France. Minerals 2020, 10, 775. [CrossRef]

Publisher's Note: MDPI stays neutral with regard to jurisdictional claims in published maps and institutional affiliations. 